\title{
Condyloma Acuminate and Increase in the Number of Human Immunodeficiency Virus-Positive Patients
}

\author{
Seung Chul Heo \\ Department of Surgery, SMG-SNU Boramae Medical Center, Seoul, Korea
}

\section{See Article on Page 294-298}

Condyloma acuminata arising from human papillomavirus (HPV) infection may cause anal squamous cell cancer and can have a recurrence rate of up to $50 \%$ of patients after surgical treatment because surgery cannot control latent HPV infection in surrounding tissue [1]. Therefore, trials using interferon, imiquimod, 5-fluorouracil, vaccine and natural products have been performed to reduce the recurrence rate. That the immune function of the host is important to the recurrence of condyloma is supported by the higher recurrences in patients with immune-suppressants and with human immunodeficiency virus (HIV) infection and by condyloma acuminate being a viral infection [2].

The incidence of HPV infection is more than twice in homosexual man than in others, and anal condyloma increases the incidence of anal cancer; hence, anal cancers are increasing in men who have sex with men [3]. With the increases in homosexuality and homosexual marriage, anal condyloma has become a disease deserving attention. Anal condylomas have more dysplasia in homosexual man and a more frequent neoplastic process in HIVpositive patients $[4,5]$. Moreover, frequent multiple infections of oncogenic HPV strains such as HPV-type 16 or 18 are seen in HIV-positive patients [6]. Highly active antiretroviral therapy is thought by some researchers to contribute to reduce morbidity and mortality due to HIV infection, resulting in a decreased incidence of HPV infection and anal cancer while other researchers suggest that prolonged survival of HIV-positive patients may increase the prevalence of anal cancers [7].

Few data exist on the incidence of anal condyloma and associ-

Correspondence to: Seung Chul Heo,M.D.

Department of Surgery, SMG-SNU Boramae Medical Center, 20 Boramae-ro 5-gil, Dongjak-gu, Seoul 156-707, Korea

Tel: +82-2-870-2273, Fax: +82-2-870-3866

E-mail:heosc3@brm.co.kr

(C) 2012 The Korean Society of Coloproctology

This is an open-access article distributed under the terms of the Creative Commons Attribution NonCommercial License (http://creativecommons.org/licenses/by-nc/3.0) which permits unrestricted noncommercial use, distribution, and reproduction in any medium, provided the original work is properly cited. ated anal squamous cell cancer in Korea. However, the increases in the number of HIV-positive patients and in their survival [8] will eventually make condyloma acuminata and associated anal cancer an important issue. As uterine cervical cancer, a typical cancer caused by HPV infection, diminishes in incidence and mortality because of publicity and education, the time to start surveillance and to increase education to prevent and to reduce the incidence of anal cancer due to HPV infection has arrived.

\section{REFERENCES}

1. Mistrangelo M, Cornaglia S, Pizzio M, Rimonda R, Gavello G, Dal Conte I, et al. Immunostimulation to reduce recurrence after surgery for anal condyloma acuminata: a prospective randomized controlled trial. Colorectal Dis 2010;12:799-803.

2. De Panfilis G, Melzani G, Mori G, Ghidini A, Graifemberghi S. Relapses after treatment of external genital warts are more frequent in HIV-positive patients than in HIV-negative controls. Sex Transm Dis 2002;29:121-5.

3. Goldstone SE, Moshier E. Detection of oncogenic human papillomavirus impacts anal screening guidelines in men who have sex with men. Dis Colon Rectum 2010;53:1135-42.

4. Metcalf AM, Dean T. Risk of dysplasia in anal condyloma. Surgery 1995;118:724-6.

5. Anderson CA, Boller AM, Richardson CJ, Balcos EG, Zera RT. Anal condyloma: a comparison between HIV positive and negative patients. Am Surg 2004;70:1014-8.

6. Moon SB, Moon SH, Park KJ. Detection and typing of human papillomavirus in anal condyloma acuminatum of HIV-positive patients. J Korean Surg Soc 2010;78:111-5.

7. Abramowitz L, Benabderrahmane D, Ravaud P, Walker F, Rioux C, Jestin C, et al. Anal squamous intraepithelial lesions and condyloma in HIV-infected heterosexual men, homosexual men and women: prevalence and associated factors. AIDS 2007;21:1457-65.

8. Korean AIDS Information Center. Current status of HIV infection in Korea [Internet]. Seoul: Korean AIDS Information Center; c2011 [cited Year 2012 Dec 12]. Available from: http://www.aidsinfo.or.kr/. 